\title{
Analysis of The Influence of Product Quality, Price, Location, and Promotion on Consumer Purchase Interest in Convection (Case Study on Dira Ashesh)
}

\author{
Azzaliya Almira \\ PT Akukawa \\ Azzaliyaalmira@gmail.com \\ https://doi.org/10.37715/rmbe.v1i2.2430
}

\begin{abstract}
The high growth of the textile industry in Indonesia and advances in the textile sector have led to the emergence of many small and medium industries in the textile sector and textile production. The large number of garment industries that have sprung up has led to increasingly fierce competition in the garment industry. The independent variables in this study are product quality $\left(X_{1}\right)$, Price $\left(X_{2}\right)$, Location $\left(X_{3}\right)$, and Promotion $\left(\mathrm{X}_{4}\right)$. The theory used in this research is marketing management theory. The dependent variable in this study is purchase intention $\left(Y_{1}\right)$. This study was conducted to determine the effect of four independent variables on convection buying interest. The object of this research is the garment industry between Surabaya and Gresik. The data collection method was carried out by distributing questionnaires to 384 respondents. Research respondents came from a sample that has been determined using the purposive sampling technique. The data in this study were obtained from questionnaires distributed online, to be analyzed using the SPSS data processing application with multiple linear regression analysis equation models. The results showed that all independent variables had an effect on the dependent variable. Garment vendor Dira Ashesh is expected to improve product quality, price, location, and promotion to increase consumer buying interest.
\end{abstract}

Keywords - Dira Ashesh, Garment, Product Quality, Price, Location, Purchase Interest Promotion, Multiple Linear Regression.

\section{Introduction}

The apparel industry sector is one of the industries in Indonesia which every year experiences very rapid development. The growth phenomenon of the apparel industry sector can be seen in the data taken from the Industrial Development Analysis Report (Edition IV - 2019) of the Ministry of Industry of the Republic of Indonesia. The phenomenon of the growth of the apparel industry is also felt in the garment business in Indonesia. This can be seen from the many convection and garment businesses that have sprung up and have competitive advantages that are increasingly innovative. Quoting news from the news portal katadata.com, according to Elis Masitoh as Director of the Textile, Leather and Footwear Industry of the Ministry of Industry (Kemenperin), revealed that the textile industry and textile production sector is one of the many other industries that provide a large role for the economy in Indonesia. Indonesia because this industry is a labor-intensive and export-oriented industry.

Dira Ashesh is a new business unit engaged in the manufacture of apparel located in the border area of Surabaya and Gresik. Established since the end of 2019, Dira Ashesh serves the needs of the community in meeting the needs of clothing with various types of models and designs that the community wants. Dira Ashesh serves the B2B and B2C markets with a comparison of the B2B market of $70 \%$ and the B2C market of only $30 \%$. The competitors provide many offers and the latest innovations, thus making consumers have many choices in determining the desired convection. Therefore, the author conducted a preliminary survey of 30 respondents in the Surabaya and Gresik areas to understand what influences buying interest in convection in the Surabaya and Gresik areas. From the results of this preliminary survey, it can be concluded that there are 4 biggest factors that influence consumers in determining buying interest in choosing convection. These 4 factors are quality, price, location, and promotion factors.

Based on the explanation that has been given, regarding what factors influence consumer buying interest in the selection of convection that has been described, it can be concluded that there are four biggest factors that are 
important to research and can be used and applied to the Dira Ashesh company so that it can increase purchase interest. . So based on the above background, the authors are interested in conducting research with the title "Analysis of the influence of product quality, price, location, and promotion on consumer buying interest in convection".

\section{Literature Review}

\subsection{Previous Research}

Research from Hanaysha (2018) entitled An Examination of the factors affecting the consumer's purchase decision in the Malaysian retail market. This study aims to examine the effects of corporate social responsibility (CSR), social media marketing, sales promotion, store environment, and perceived value in purchasing decisions in the retail sector. From this study it was found that Corporate Social Responsibility (CSR) has a significant positive effect on purchasing decisions, however, marketing activities carried out in social media have an insignificant negative effect. The store environment also has a significant positive influence. However, promotions have a negative influence on purchasing decisions. Because more and more discounts are given, it actually gives a sense of discomfort and anxiety among consumers. Because low prices tend to have low quality. Attachment to the research is the use of promotion variables.

Kurniawan and Sari (2017) with the title "Pengaruh Kualitas Produk, Harga, Dan Kepercayaan Terhadap Proses Keputusan Pembelian Konsumen Perusahaan Konveksi Inglorius Industries di Kota Bandung". The result of this research is that trust has the most influence on consumer buying interest compared to product quality and price. The relationship with this research is product quality and price with the same case study, namely in convection.

\subsection{Theoretical basis}

\subsubsection{Marketing Management}

Hasibuan (2016, p. 9) states that management is a science that utilizes human resources and other resources effectively and efficiently for long-term goals. According to Kotler and Keller (2016, p. 26) marketing management as the art science of choosing target markets and getting, keeping, and growing customers through creating, delivering, and communicating. From the above understanding, the author's understanding that marketing management is an activity that starts from analyzing, implementing, and controlling everything that has been designed to achieve organizational goals in the long term. Marketing management has a very important role in the survival of the company in order to gain profits in achieving the goals that have been set.

\subsubsection{Product quality}

Product is the output or result of one of the company's activities or activities that are offered to the market in order to meet consumer desires. Therefore, a product must have advantages over other products, one of which can be from the quality offered. According to Kotler (2010, as cited in Syaparilwadi \& Wardhana, 2015, p. 5) product quality can be included in 9 dimensions, namely form (shape), product characteristics (features), performance (performance), conformance to specifications (conformance to specifications), durability (durability), reliability (reliability), ease of repair (repairability), style (style), design (design).

\subsubsection{Price}

Price is one of the most important parts because price is a medium of exchange in transactions. Price is a variable that can be controlled and determines whether or not a product or service is accepted in the market. In this case, there are 5 objectives for determining the price according to Amrullah and Agustin (2016, p. 4), namely: Increasing sales, Maintaining and improving market share, Stabilizing investment, Achieving maximum profit. Price indicators according to Kotler and Armstrong (2011, as cited in Amrullah \& Agustin, 2016, p. 4) are divided into 4, namely price affordability, price suitability with the quality of the product provided, price competitiveness.

2.2.4. Location

Tjiptono (2015, p. 345) states that location refers to various company marketing activities that aim to expedite and facilitate the delivery or distribution of goods from factories to consumers. In choosing a location, there are several factors to consider. Echdar (2013, as cited in Mimi, 2015, p. 93) states as follows: Availability of resources, Personal considerations, Lifestyle considerations, Ease of reaching consumers. According to Aprih and Widowati (2011, as cited in Gunawan, 2016, p. 16) location is defined as a place to carry out daily business activities. Indicators of location are affordability, fluency, proximity to the home of the business owner. While the 
location indicators according to Tjiptono (2015, as cited in Kuswatiningsih, 2016, p. 15) are as follows: access, visibility, traffic (traffic), parking lots, expansion, environment, competitors, government regulations.

\subsubsection{Promotion}

Tjiptono (2015, p. 387) states that promotion is one element in the marketing mix that focuses on efforts to inform, persuade, and remind consumers about the company's brands and products. The promotional mix according to Kotler and Keller (2016: 582) is the marketing communication mix or better known as the promotion mix, namely advertising (advertising), sales promotion (sales promotion), events and experiences (events and experiences), public relations and publicity. (public relations and publicity), direct marketing and database (direct marketing), online and social media marketing (online marketing and social media), mobile marketing (mobile marketing), personal selling (personal selling).

\subsubsection{Buying Interest}

Buying interest is something that consumers do before planning to buy a product. Buying interest arises because of a stimulus that is influenced by several variables that are interrelated with one another so that it influences consumers to buy and use a product. These stages are described in the AIDA concept developed by Kotler (2009). The first stage, namely the cognitive state stage, is Attention. The second stage is the affective stage. In this stage there are two, namely interest and desire. The last stage is behavior, namely action. Indicators of buying interest according to Suwandari (2008, as cited in Nasution \& others, 2014) can be seen with the following characteristics: attention, interest, desire, action.

\section{Research Methods}

3.1. Analysis Model

\subsection{Research Hypothesis}

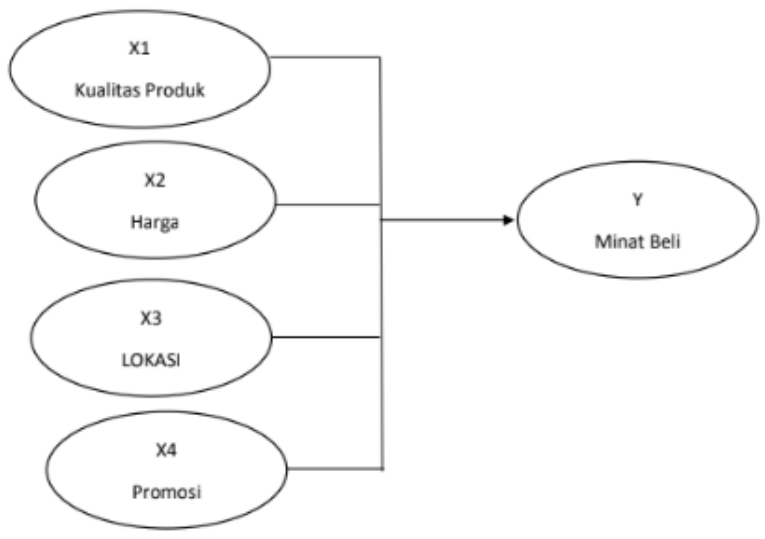

Figure 3.1. Analysis Model

Sources: Data processed, 2021

- H1: Product quality has a positive and significant effect on buying interest.

- $\mathrm{H} 2$ : Price has a positive and significant effect on buying interest

- H3 : Location has a positive and significant effect on buying interest.

- H4 : Promotion has a positive and significant effect on buying interest.

\subsection{Research Approach}

The type of research conducted by the researcher is quantitative research. The research method used in this study is a survey method where this research method has a decision-making technique in the form of written and oral question data. The research sites observed in this study are the cities of Surabaya and Gresik, because Dita Ashesh is located between the borders of Surabaya and Gresik. This research was conducted for two months, from November 2020 to December 2020. The population of this research is all potential consumers whose numbers are not known with certainty or can be called the infinite population. The sample was determined using the Cochran formula (1997, as cited in Suliyanto, 2018, p. 200). In this study the sample was calculated with a $95 \%$ confidence level $(Z=1.96)$. Meanwhile, the highest sample error rate that can still be tolerated (Margin of Error) is $5 \%$. 


$$
\begin{gathered}
n=\frac{Z^{2}}{A d^{2}} \\
n=\frac{1,96^{2}}{4(0,05)^{2}}=384,16
\end{gathered}
$$

Description :

$\mathrm{n}=$ Number of Samples

$\mathrm{Z}=$ Confidence Level

$\mathrm{d}=$ Fault tolerance level (Margin of Error)

The criteria for the sample of respondents in this study are: prospective customers of Dira Ashesh, namely men and women aged 20-40 years in Surabaya and Gresik and have made orders to convection for the benefit of individuals (end users). Sources of data used in this study are primary data and secondary data. Primary data were collected through the distribution of questionnaires either offline or online using google form media on the choice of stimuli. The measurement scale for this research variable uses a Likert scale according to the Oei theory (2010, p. 87), as follows:

\begin{tabular}{|c|l|}
\multicolumn{2}{|c|}{ Table 3.1 Research Likert Scale } \\
\hline Mark & \multicolumn{1}{|c|}{ Criteria } \\
\hline 1 & Strongly Disagree (STS) \\
\hline 2 & Disagree (TS) \\
\hline 3 & Simply Agree (CS) \\
\hline 4 & Agree (S) \\
\hline 5 & Strongly Agree (SS) \\
\hline
\end{tabular}

\section{Research variable}

Product Quality = Independent Variable (X1)

Price $=$ Independent Variable $(\mathrm{X} 2)$

Location $=$ Independent Variable $(\mathrm{X} 3)$

Promotion $=$ Independent Variable $(\mathrm{X} 4)$

Buying Interest $=$ Related Variable $(Y)$

\subsection{Methods of Data Analysis and Hypothesis Testing}

\subsubsection{Multiple linear regression analysis}

The multiple regression equation can be formulated as follows:

\section{Description:}

$$
Y=\alpha+\beta_{1} X_{1}+\beta_{2} X_{2}+\beta_{3} X_{3}+\beta_{4} X_{4}+\varepsilon
$$

$$
\begin{array}{ll}
\mathrm{Y} & =\text { Impulse Buying Behavior } \\
\alpha & =\text { Constant } \\
\beta_{1}, \beta_{2}, \beta_{3}, \beta_{4} & =\text { Variable Regression Coefficient } \\
X_{1} & =\text { Product Quality Variable } \\
X_{2} & =\text { Price Variable } \\
X_{3} & =\text { Location Variable } \\
X_{4} & =\text { Promotion Variable } \\
\varepsilon & =\text { Error / (error rate and model accuracy) }
\end{array}
$$

a. Validity and Reliability Test

Measurement of validity in this study using the Pearson product moment correlation. If the Pearson product moment correlation value between the questions in the questionnaire and the total score produces a significance value, it is declared valid (Sugiyono, 2017). While valid. Reliability measurement is done by means of one shot or measuring only once with SPSS data processing software statistical test of the Cronbach alpha coefficient on the condition that it can be said to be reliable if the Cronbach alpha value is $>$ 0.60. (Sugiyono, 2017).

b. Classic assumption test

1. Normality test 
The method used is the Kolmogorov-Smirnov non-parametric statistical test with the condition that the significance value is greater than 0.05 . If the significance value is less than 0.05 then the data is not normally distributed (Priyanto, 2014).

2. Multicollinearity test

As for detecting the presence or absence of multicollinearity in the regression model, it can be seen from the tolerance value or Variance Inflation Factor (VIF) with the following formula (Santoso, 2012, p. 234).

$$
V I F=\frac{1}{1-R_{1}^{2}}
$$

3. Heteroscedasticity Test

The model used is the Glesjer symptom. The absolute $t$-count value lies between $+t$ label with df(nk-1) and a significant level of 0.05 then heteroscedasticity occurs (Santoso, 2011).

c. T test

To test whether each independent variable has a significant effect on the related variables partially $=0.05$ and also accepts or rejects the hypothesis, the method used is

1) Formulate a hypothesis

If $\mathrm{H}_{0} 1: 1=0$, then the dependent variable has no effect on the independent variable partially.

If $\mathrm{H}_{\mathrm{a}} 1: \beta 1>0$, then the effect on the dependent variable, independent variable partially.

1) Looking for $t$ count

Description :

$$
t=\frac{R \sqrt{n-2}}{\sqrt{1-R^{2}}}
$$

$\mathrm{R}=$ Correlation Coefficient

$\mathrm{R}^{2}=$ Coefficient of Determination

$\mathrm{N}=$ Number of samples

Assuming ( $t$ count):

$\mathrm{H} 0: \mathrm{H} 1, \mathrm{H} 2, \mathrm{H} 3$, accepted if sig $>=0.05$

$\mathrm{H} 0: \mathrm{H} 1, \mathrm{H} 2, \mathrm{H} 3$, rejected if sig $=0.05$

d. F Uji test

The $\mathrm{F}$ test tests whether the independent variables together have an effect on the dependent variable. The statistical test used in the F Test or the usual Analysis of Variance (ANOVA). According to Sugiyono (2017, p. 192), the following double correlation significant formula can be used:

$$
F h=\frac{\frac{R^{2}}{k}}{\frac{\left(1-R^{2}\right)}{(n-k-1)}}
$$

Description :

$\mathrm{R}^{2} \quad=$ Multiple correlation coefficient

$\mathrm{k} \quad=$ Number of independent variables

$\mathrm{n} \quad=$ Number of sample members

$\mathrm{Dk} \quad=(\mathrm{n}-\mathrm{k}-1)$ degrees of freedom

Then the hypothesis is:

$\mathrm{H}_{0}: \rho=0$ means that the dependent variable is significant to the independent variable

$\mathrm{H}_{\alpha}: \rho \neq 0$ means a significant effect on the dependent variable, independent variable

a. Coefficient of Determination Test $\left(\mathrm{R}^{2}\right)$

Test $\mathrm{R}^{2}$ aims to measure how far the model can explain the variations of the independent variables. The value of the coefficient of determination is $0-1$. If :

- The value of $\mathrm{R}^{2}>1$ means that the ability of the independent variable variation to run all the variable variations is very limited.

- If the value of $\mathrm{R}^{2}$ is close to 1 , then the variation of the independent variable close to perfect (Ghozali, 2018). 


\section{Result and Discussion}

\subsection{Object of research}

Dira Ashesh is a company engaged in the production and service of clothing, convection, micro garments located on the border of Surabaya and Gresik. Specifically, convection is a small industry which is a place for making ready-made clothes such as t-shirts, uniforms, polo, shirts, shirts, etc. The focus of this company is to support companies or organizations that need garment attributes.

\subsection{Respondents Overview}

The majority of respondents in this study were almost evenly matched between men and women, but men slightly outnumbered women (with the percentage of men being 50.8\%). This shows that the majority of men have ordered clothes or other garment attributes at convection.

Table 4.1. Job Distribution of Respondents

\begin{tabular}{|l|l|l|l|}
\hline No & Pekerjaan Responden & Jumlah & Prosentase \\
\hline 1 & Karyawan & 113 & $29.4 \%$ \\
\hline 2 & Mahasiswa & 146 & $38 \%$ \\
\hline 3 & Wiraswasta & 110 & $28.6 \%$ \\
\hline 4 & Guru & 6 & $1.6 \%$ \\
\hline 5 & Freelance & 2 & $0.5 \%$ \\
\hline 6 & UKM & 2 & $0.5 \%$ \\
\hline 7 & Wirausaha & 2 & $0.5 \%$ \\
\hline 8 & Dosen & 1 & $0.3 \%$ \\
\hline 9 & Full time Programmer & 1 & $0.3 \%$ \\
\hline 10 & Trainee & 1 & $0.3 \%$ \\
\hline Total & & 384 & $100 \%$ \\
\hline
\end{tabular}

Source: Results of Author's Data Processing.

Refer to table 4.1. it can be seen that the majority of respondents work as students, which is $38 \%$ of the total respondents in this study. This shows that the majority of students have used convection services in the Surabaya and Gresik areas.

\subsubsection{Description of Respondents' Answers}

1. Product quality $\left(\mathrm{X}_{1}\right)$

Table 4.2. Description of Product Quality Variable Answer

\begin{tabular}{|c|c|c|c|c|c|c|c|c|c|}
\hline \multirow{2}{*}{ No } & \multirow{2}{*}{ Statement } & \multicolumn{5}{|c|}{ Number of Answers } & \multirow{2}{*}{ Mean } & \multirow{2}{*}{ Category } & \multirow{2}{*}{$\begin{array}{l}\text { Standard } \\
\text { Deviation }\end{array}$} \\
\hline & & 1 & 2 & 3 & 4 & 5 & & & \\
\hline 1 & $\begin{array}{l}\text { I choose convection according to the } \\
\text { shape I want } \\
\text { for }\end{array}$ & 0 & 0 & 15 & 282 & 87 & 4.18 & Agree & 0.48 \\
\hline 2 & $\begin{array}{l}\text { I choose a convection that can } \\
\text { produce the goods I want quickly and } \\
\text { on time. }\end{array}$ & 0 & 0 & 49 & 313 & 22 & 3.92 & Just Agree & 0.42 \\
\hline 3 & $\begin{array}{l}\text { I choose convection according to my } \\
\text { specifications } \\
\text { want }\end{array}$ & 0 & 2 & 29 & 312 & 41 & 4.02 & Agree & 0.45 \\
\hline 4 & $\begin{array}{l}\text { I choose convection that can inspire } \\
\text { me what style } \\
\text { that fits my needs }\end{array}$ & 0 & 3 & 63 & 297 & 21 & 3.87 & Just Agree & 0.48 \\
\hline 5 & $\begin{array}{l}\text { I choose convection that matches the } \\
\text { design I want }\end{array}$ & 0 & 3 & 20 & 310 & 51 & 4.06 & Agree & 0.46 \\
\hline & Product quality & & & & & & 4.01 & Agree & \\
\hline
\end{tabular}

The first statement has the highest mean value of 4.18. The first statement has the largest standard deviation compared to other statements, so it can be concluded that the respondents' answers to these statements are the most heterogeneous compared to respondents' answers to other statements. 


\section{Price $\left(\mathrm{X}_{2}\right)$}

Table 4.3. Description of Price Variable Answer

\begin{tabular}{|c|c|c|c|c|c|c|c|c|c|}
\hline \multirow{2}{*}{ No } & \multirow{2}{*}{ Statement } & \multicolumn{5}{|c|}{ Number of Answers } & \multirow{2}{*}{ Mean } & \multirow{2}{*}{ Category } & \multirow{2}{*}{$\begin{array}{l}\text { Standard } \\
\text { Deviation }\end{array}$} \\
\hline & & 1 & 2 & 3 & 4 & 5 & & & \\
\hline 1 & $\begin{array}{l}\text { I choose Convection which has an } \\
\text { affordable price with my budget }\end{array}$ & 0 & 0 & 30 & 258 & 96 & 4.17 & Agree & 0.54 \\
\hline 2 & $\begin{array}{l}\text { I choose convection that can provide } \\
\text { quality according to the price offered }\end{array}$ & 0 & 0 & 58 & 283 & 43 & 3.96 & Just Agree & 0.51 \\
\hline 3 & $\begin{array}{l}\text { I chose convection because it has a } \\
\text { more affordable price than other } \\
\text { convection }\end{array}$ & 0 & 2 & 44 & 290 & 50 & 4.01 & Agree & 0.49 \\
\hline & Price & & & & & & 4.04 & Agree & \\
\hline
\end{tabular}

The first statement has a mean of 4.17 and the highest standard deviation, so it can be concluded that respondents choose convection that has affordable prices according to their budget and this statement is the most heterogeneous compared to respondents' answers to other statements.

1. Location $\left(\mathrm{X}_{3}\right)$

Table 4.4. Location Variable Answer Description

\begin{tabular}{|c|c|c|c|c|c|c|c|c|c|}
\hline \multirow{2}{*}{ No } & \multirow{2}{*}{ Statement } & \multicolumn{5}{|c|}{ Number of Answers } & \multirow{2}{*}{ Mean } & \multirow{2}{*}{ Category } & \multirow{2}{*}{$\begin{array}{l}\text { Standard } \\
\text { Deviation }\end{array}$} \\
\hline & & 1 & 2 & 3 & 4 & 5 & & & \\
\hline 1 & $\begin{array}{l}\text { I choose convection with easy access } \\
\text { to reach }\end{array}$ & 0 & 0 & 20 & 279 & 85 & 4,16 & Agree & 0,49 \\
\hline 2 & $\begin{array}{l}\text { I choose convection that is easy to see } \\
\text { from afar }\end{array}$ & 0 & 3 & 63 & 280 & 38 & 3,91 & Just Agree & 0,53 \\
\hline 3 & $\begin{array}{l}\text { I choose a convection that is not far } \\
\text { from the location where I work }\end{array}$ & 0 & 1 & 41 & 292 & 50 & 4,01 & Agree & 0,49 \\
\hline 4 & $\begin{array}{l}\text { I chose convection because of the } \\
\text { availability of parking space }\end{array}$ & 0 & 1 & 73 & 273 & 37 & 3,90 & Just Agree & 0,53 \\
\hline \multicolumn{7}{|c|}{ Location } & 4,00 & Agree & \\
\hline
\end{tabular}

The first statement has a mean of 4.16 and the highest standard deviation, so it can be concluded that the respondents chose convection based on the ease of access to the location, namely easy access to public transportation or online transportation. In addition, the statement is the most heterogeneous compared to the respondents' answers to other statements.

\section{Promosi $\left(\mathrm{X}_{4}\right)$}

Table 4.5. Promotion Variable Answer Description

\begin{tabular}{|c|c|c|c|c|c|c|c|c|c|}
\hline \multirow{2}{*}{ No } & \multirow{2}{*}{ Statement } & \multicolumn{5}{|c|}{ Number of Answers } & \multirow{2}{*}{ Mean } & \multirow{2}{*}{ Category } & \multirow{2}{*}{$\begin{array}{l}\text { Standard } \\
\text { Deviation }\end{array}$} \\
\hline & & 1 & 2 & 3 & 4 & 5 & & & \\
\hline 1 & $\begin{array}{l}\text { I choose a convection that offers a lot } \\
\text { of promotions }\end{array}$ & 0 & 1 & 20 & 263 & 100 & 4.20 & Agree & 0.53 \\
\hline 2 & $\begin{array}{l}\text { I choose a convection that offers } \\
\text { promotions with good quality }\end{array}$ & 0 & 0 & 40 & 282 & 62 & 4.05 & Agree & 0.51 \\
\hline 3 & $\begin{array}{l}\text { I choose a convection that offers } \\
\text { promotions with value } \\
\text { the good one }\end{array}$ & 0 & 1 & 21 & 287 & 75 & 4.13 & Agree & 0.49 \\
\hline 4 & $\begin{array}{l}\text { I choose a convection that offers } \\
\text { promotions according to my needs. }\end{array}$ & 0 & 1 & 59 & 272 & 52 & 3.97 & Just Agree & 0.54 \\
\hline & Promotion & & & & & & 4,09 & Agree & \\
\hline
\end{tabular}

The first statement has a mean of 4.16 and the highest standard deviation, so it can be concluded that the respondents chose convection based on the ease of access to the location, namely easy access to public transportation 
or online transportation. In addition, the statement is the most heterogeneous compared to the respondents' answers to other statements.

3. Buying Interest (Y)

Table 4.6. Description of Answers for Buying Interest Variables

\begin{tabular}{|c|c|c|c|c|c|c|c|c|c|}
\hline \multirow{2}{*}{ No } & \multirow{2}{*}{ Statement } & \multicolumn{5}{|c|}{ Number of Answers } & \multirow{2}{*}{ Mean } & \multirow{2}{*}{ Category } & \multirow{2}{*}{$\begin{array}{c}\text { Standard } \\
\text { Deviation }\end{array}$} \\
\hline & & 1 & 2 & 3 & 4 & 5 & & & \\
\hline 1 & $\begin{array}{l}\text { Before determining convection, I pay } \\
\text { attention to what products } \\
\text { offered by convection }\end{array}$ & 0 & 0 & 1 & 250 & 133 & 4.34 & Agree & 0.48 \\
\hline 2 & $\begin{array}{l}\text { Before deciding on convection, I was } \\
\text { interested in the products offered by } \\
\text { convection }\end{array}$ & 0 & 0 & 5 & 276 & 103 & 4.25 & Agree & \\
\hline 3 & $\begin{array}{l}\text { Before deciding on convection, I felt } \\
\text { like buying the products offered by } \\
\text { convection }\end{array}$ & 0 & 0 & 1 & 295 & 88 & 4.22 & Agree & \\
\hline 4 & $\begin{array}{l}\text { Before determining convection, I } \\
\text { believe in the products offered by } \\
\text { convection. }\end{array}$ & 0 & 0 & 12 & 284 & 88 & 4.19 & Agree & \\
\hline & Buying Interest & & & & & & 4.25 & Agree & \\
\hline
\end{tabular}

It can be understood that the average mean of the Product Quality Variables $\left(\mathrm{X}_{1}\right)$, Price $\left(\mathrm{X}_{2}\right)$, Location $\left(\mathrm{X}_{3}\right)$, Promotion $\left(\mathrm{X}_{4}\right)$ and Purchase Interest $(\mathrm{Y})$ is the highest from the Purchase Intention variable which reaches 4, 25 so that it can be understood if the respondents as a whole strongly agree with the statements in the buying interest variable. The first statement has a mean of 4.34 and the highest standard deviation, so it can be concluded that respondents choose convection because they are concerned about what products are offered by convection. In addition, the statement is the most heterogeneous compared to respondents' answers to other statements.

\subsection{Data Analysis Results}

\subsubsection{Instrument Test}

a. Validity test

Table 4.7. Validity Test Results

\begin{tabular}{|l|l|l|l|}
\hline \multicolumn{5}{|l|}{ No Item } & Signifikansi & Nilai Signifikansi & Keterangan \\
\hline Variabel X1 & 0.000 & 0,05 & Valid \\
\hline X1.1 & 0.000 & 0,05 & Valid \\
\hline X1.2 & 0.000 & 0,05 & Valid \\
\hline X1.3 & 0.000 & 0,05 & Valid \\
\hline X1.4 & 0.000 & 0,05 & Valid \\
\hline X1.5 & 0.000 & \multicolumn{2}{l|}{} \\
\hline Variabel X2 & 0.000 & 0,05 & Valid \\
\hline X2.1 & 0.000 & 0,05 & Valid \\
\hline X2.2 & & 0,05 & Valid \\
\hline X2.3 & 0.000 & & Valid \\
\hline Variabel X3 & 0.000 & 0,05 & Valid \\
\hline X3.1 & 0.000 & 0,05 & Valid \\
\hline X3.2 & 0.000 & 0,05 & Valid \\
\hline X3.3 & & 0,05 & \\
\hline X3.4 & & & \\
\hline Variabel X4 & & & \\
\hline
\end{tabular}




\begin{tabular}{l|l|l|l|}
\hline X4.1 & 0.000 & 0,05 & Valid \\
\hline X4.2 & 0.000 & 0,05 & Valid \\
\hline X4.3 & 0.000 & 0,05 & Valid \\
\hline X4.4 & 0.000 & 0,05 & Valid \\
\hline Variabel Y & \multicolumn{5}{|l|}{} \\
\hline Y1.1 & 0.000 & 0,05 & Valid \\
\hline Y1.2 & 0.000 & 0,05 & Valid \\
\hline Y1.3 & 0.000 & 0,05 & Valid \\
\hline Y1.4 & 0.000 & 0,05 & Valid \\
& Source: Results of Author's Data Processing
\end{tabular}

The correlation method uses the principle of correlating between each instrument score and the total score of the instrument. The results of the validity test prove that all the indicator scores used have a significance value of $<0.05$. The test results in the table above show that all of these indicators are valid.

b. Reliability Test

Table 4.8. Reliability Test Results

\begin{tabular}{|l|l|l|l}
\hline Variabel & Cronbach alpha & $\begin{array}{l}\text { Nilai Cronbach } \\
\text { alpha }\end{array}$ & Keterangan \\
\hline Kualitas produk & 0.6 & 0.833 & Reliabel \\
\hline Harga & 0.6 & 0.844 & Reliabel \\
\hline Lokasi & 0.6 & 0.864 & Reliabel \\
\hline Promosi & 0.6 & 0.873 & Reliabel \\
\hline Minat Beli & 0.6 & 0.682 & Reliabel \\
& & &
\end{tabular}

Source: Results of Author's Data Processing

The results of the reliability test prove that all the instruments used have a Cronbach Alpha value $>0.6$ and it can be stated that the instrument of each variable in the questionnaire is suitable to be a measuring tool.

\subsubsection{Classic assumption test}

a. Normality test

Table 4.9. Kolmogrov-Smirnov Test One-Sample Normality Test Table

\begin{tabular}{|l|l|l|} 
& & $\begin{array}{l}\text { Unstandardiz } \\
\text { Residual }\end{array}$ \\
\hline $\begin{array}{l}\text { Normal } \\
\text { Parametersa }\end{array}$ & Mean & $\begin{array}{l}384 \\
.0000000\end{array}$ \\
Most Extreme & $\begin{array}{l}\text { Std. Deviation } \\
\text { Differences }\end{array}$ & .91256275 \\
& Absolute & .052 \\
Kolmogrov- \\
$\begin{array}{l}\text { Smirnov Z } \\
\text { Asymp. Sig. (2- } \\
\text { tailed) }\end{array}$ & Positive & 0.052 \\
& & -.036 \\
Negative & 1.024 \\
\hline
\end{tabular}

Source: Results of Author's Data Processing

The results of the normality test showed that all the instruments used had a significance value of $>0.05$, which was 0.245 . Therefore it can be stated that the residuals are normally distributed. 
b. Multicollinearity Test

Table 4.10. Multicollinearity Test Results

\begin{tabular}{|c|c|c|c|c|c|c|c|c|}
\hline \multirow{2}{*}{\multicolumn{2}{|c|}{ Model }} & \multicolumn{2}{|c|}{$\begin{array}{l}\text { Unstandardized } \\
\text { Coefficients }\end{array}$} & \multirow{2}{*}{$\begin{array}{l}\begin{array}{l}\text { Standardized } \\
\text { Coefficients }\end{array} \\
\text { Beta }\end{array}$} & \multirow[t]{2}{*}{$t$} & \multirow[t]{2}{*}{ Sig } & \multicolumn{2}{|c|}{$\begin{array}{l}\text { Collinearity } \\
\text { Statistics }\end{array}$} \\
\hline & & \multirow{2}{*}{$\begin{array}{l}\text { B } \\
5.153\end{array}$} & \multirow{2}{*}{$\begin{array}{l}\begin{array}{l}\text { Std. } \\
\text { Error }\end{array} \\
.667\end{array}$} & & & & \multirow[t]{2}{*}{ Tolerance } & \multirow[t]{2}{*}{ VIF } \\
\hline 1 & (Constant) & & & & 7.723 & .000 & & \\
\hline & $\begin{array}{l}\text { Kualitas } \\
\text { Produk }\end{array}$ & .095 & .029 & .128 & 3.266 & .001 & .824 & 1.214 \\
\hline & Harga & .399 & .041 & .411 & 9.697 & .000 & .704 & 1.421 \\
\hline & Lokasi & .203 & .034 & .267 & 6.022 & .000 & .640 & 1.563 \\
\hline & Promosi & 115 & .030 & .155 & 3.779 & .000 & .753 & 1.327 \\
\hline
\end{tabular}

a. Dependent Variable : Buying Interest

Source: Appendix C-11 Results of Author's Data Processing.

Multicollinearity test results show that the tolerance value for the four independent variables is more than 0.1 , namely $0.824 ; 0.704 ; 0.640 ; 0.753$ and the value of VIF on the four variables is less than 10 , namely $1.214 ; 1.421 ; 1,563 ; 1,327$. It can be concluded that all variables do not have multicollinearity symptoms in a regression model.

c. Heteroscedasticity Test

Table 4.11. Heteroscedasticity Test Results

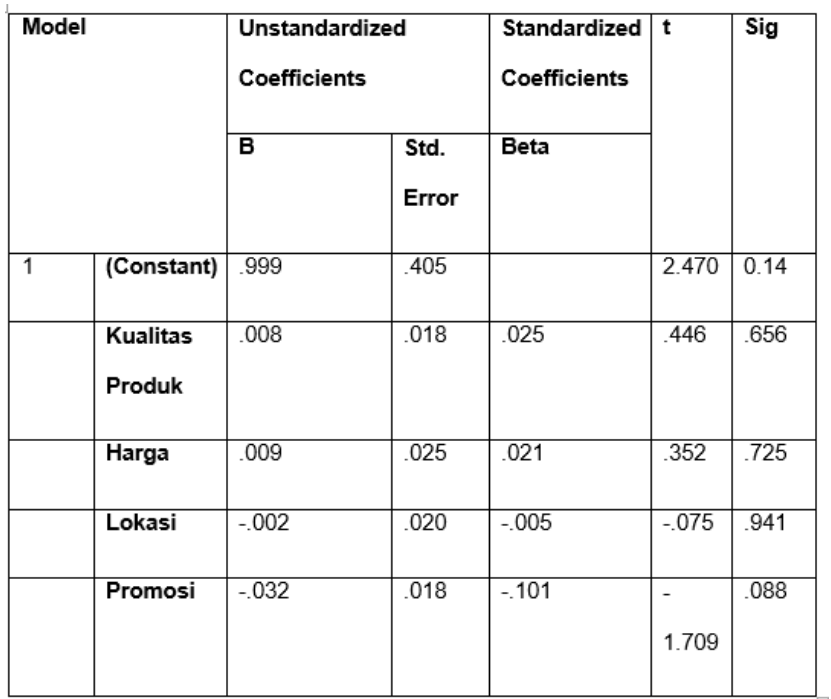

a Dependent Variable : abs Res

Source: Author's Data Processing.

The results of the Glesjer test show that all variables have a significance value $>0.05$, which means that all variables in this study do not contain symptoms of heteroscedasticity or have homogeneous variance.

4.2.3. Multiple Linear Regression Analysis

Tabel 4.12. Multiple Linear Regression Analysis Test Results

\begin{tabular}{|l|l|l|l|l|l|l|}
\hline \multicolumn{2}{|l|}{ Model } & \multicolumn{2}{l|}{$\begin{array}{l}\text { Unstandardized } \\
\text { Coefficients }\end{array}$} & $\begin{array}{l}\text { Standardized } \\
\text { Coefficients }\end{array}$ & t & Sig \\
\cline { 3 - 6 } \multicolumn{2}{|l|}{} & B & $\begin{array}{l}\text { Std. } \\
\text { Error }\end{array}$ & Beta & & \\
\hline 1 & (Constant) & 5.153 & .667 & & 7.723 & .000 \\
\hline & $\begin{array}{l}\text { Kualitas } \\
\text { Produk }\end{array}$ & .095 & .029 & .128 & 3.266 & .001 \\
\hline & Harga & .399 & .041 & .411 & 9.697 & .000 \\
\hline & Lokasi & .203 & .034 & .267 & 6.022 & .000 \\
\hline & Promosi & .115 & .030 & .155 & 3.779 & .000 \\
\hline
\end{tabular}

a a. Dependent Variable : Buying Interest Source: Results of Author's Data Processing.

The multiple linear regression equation model obtained from the test results is written in the form of a regression equation as follows: 


$$
\begin{aligned}
& \mathrm{Y}=5,153+0,095 \mathrm{X}_{1}+0,399 \mathrm{X}_{2}+0,203 \mathrm{X}_{3}+0,115 \mathrm{X}_{4} \\
& \text { Constant }(\alpha)=5,153
\end{aligned}
$$

This means: if the value of $\mathrm{X}_{1}, \mathrm{X}_{2}, \mathrm{X}_{3}$ and $\mathrm{X}_{4}$ is equal to zero (no change), then the value of $\mathrm{Y}$ is 5.153 .

The equation has the following definition:

1. Regression coefficient $\left(\mathrm{X}_{1}\right)$ Product Quality $=0,099$

It means: the positive regression coefficient is 0.099 with a significance value of 0.000 . If the other independent variables have a fixed value and variable $\mathrm{X}_{1}$ increases by 1 unit, then $\mathrm{Y}$ will also increase by 0.099. The regression coefficient of the product quality variable is 0.099 which means it has a positive effect and has a significant effect on buying interest.

2. Regression coefficient $\left(X_{2}\right)$ Price $=0.399$

It means: the positive regression coefficient is 0.399 . If another independent variable value is fixed and $\mathrm{X}_{2}$ increased by 1 unit, then $\mathrm{Y}$ will increase by 0.399 . The price variable regression coefficient is 0.399 which means it has a positive and significant effect on buying interest.

3. Regression coefficient $\left(\mathrm{X}_{3}\right)$ Location $=0.203$

It means: the positive regression coefficient is 0.203 . If another independent variable value is fixed and $\mathrm{X}_{3}$ increased by 1 unit, then $\mathrm{Y}$ will increase by 0.203 . The regression coefficient for the location variable is 0.203 , which means it has a positive and significant effect on buying interest.

4. Regression coefficient $\left(\mathrm{X}_{4}\right)$ Promotion $=0.115$

It means: the positive regression coefficient is 0.115 . If another independent variable value is fixed and $\mathrm{X}_{3}$ increased by 1 unit, then $\mathrm{Y}$ will increase by 0,115 . Promotion variable regression coefficient is 0.115 which means it has a positive and significant effect on buying interest.

4.2.4. Hypothesis testing

a. Partial Significance Test (T Test)

\begin{tabular}{|c|c|c|c|c|c|c|}
\hline \multicolumn{2}{|c|}{ Model } & \multicolumn{2}{|c|}{$\begin{array}{l}\text { Unstandardized } \\
\text { Coefficients }\end{array}$} & \multirow{2}{*}{$\begin{array}{l}\text { Standardized } \\
\text { Coefficients } \\
\text { Beta }\end{array}$} & \multirow[t]{2}{*}{$\mathbf{t}$} & \multirow[t]{2}{*}{ Sig } \\
\hline & & B & $\begin{array}{l}\text { Std. } \\
\text { Error }\end{array}$ & & & \\
\hline 1 & (Constant) & 5.153 & .667 & & 7.723 & .000 \\
\hline & $\begin{array}{l}\text { Kualitas } \\
\text { Produk }\end{array}$ & .095 & .029 & .128 & 3.266 & .001 \\
\hline & Harga & .399 & .041 & .411 & 9.697 & .000 \\
\hline & Lokasi & .203 & .034 & .267 & 6.022 & .000 \\
\hline & Promosi & .115 & .030 & .155 & 3.779 & .000 \\
\hline
\end{tabular}

Table 4.13. $\mathbf{T}$. Test Results

a. Dependent Variable: Buying Interest

Source: Results of Author's Data Processing.

The results obtained with the help of the SPSS program obtained that:

1. Product Quality Variable

Siginifikansi value of the variable $\left(\mathrm{X}_{1}\right)$ Quality of Products $<0.05$ is 0.001 and the regression coefficient is positive, namely 0.095 . This means that there is a significant positive influence individually on product quality variables on buying interest.

2. Price Variable

The significant value of the variable $\left(\mathrm{X}_{2}\right)$ is $<0.05$, which is 0.000 and the regression coefficient is positive, namely 0.399 . This means that there is a significant positive influence individually on the price variable on buying interest.

3. Location Variable

The significance value of 6 variables $\left(\mathrm{X}_{3}\right)$ Location $<0.05$ is 0.000 and the positive regression coefficient is 0.203 . This means that there is a significant positive influence individually on the location variable on buying interest.

4. Promotion Variable 
The significance value of the variable $\left(\mathrm{X}_{3}\right)$ Promotion $<0.05$ is 0.000 and the regression coefficient is positive, namely 0.115 . This means that there is a significant positive influence individually on the location variable on buying interest.

b. Simultaneous Significance Test (F Test)

Table 4.14. F Test Results

\begin{tabular}{|l|l|l|l|l|l|l|}
\hline \multicolumn{2}{|l|}{ Model } & $\begin{array}{l}\text { Sum of } \\
\text { Squares }\end{array}$ & df & $\begin{array}{l}\text { Mean } \\
\text { Square }\end{array}$ & F & Sig. \\
\hline 1 & Regression & 347.838 & 4 & 86.959 & 103.331 & $.000^{\mathrm{a}}$ \\
\hline & Residual & 318.951 & 379 & .842 & & \\
\hline & Total & 666.789 & 383 & & & \\
\hline
\end{tabular}

a. Predictors : (Constant), Promotion, Product Quality, Price, Location

b. Dependent Variable : Buying Interest

Source: Results of Author's Data Processing.

It can be seen that the value of Sig. $=0.000$. If $0.000<0.05$, it can be concluded that there is a jointly significant influence between product quality, price, location, and promotion on buying interest.

c. Coefficient of Determination Test (Test $\mathrm{R}^{2}$ )

Table 4.15. Test Results $\mathrm{R}^{2}$

\begin{tabular}{|l|l|l|l|l|l|l|}
\hline \multicolumn{2}{|l|}{ Model } & \multicolumn{2}{|l|}{$\begin{array}{l}\text { Unstandardized } \\
\text { Coefficients }\end{array}$} & \multicolumn{2}{l|}{$\begin{array}{l}\text { Standardized } \\
\text { Coefficients }\end{array}$} & Sig \\
\cline { 3 - 5 } & B & $\begin{array}{l}\text { Std. } \\
\text { Error }\end{array}$ & Beta & & \\
\hline 1 & (Constant) & 5.153 & .667 & & 7.723 & .000 \\
\hline & $\begin{array}{l}\text { Kualitas } \\
\text { Produk }\end{array}$ & .095 & .029 & .128 & 3.266 & .001 \\
\hline & Harga & .399 & .041 & .411 & 9.697 & .000 \\
\hline & Lokasi & .203 & .034 & .267 & 6.022 & .000 \\
\hline & Promosi & 115 & .030 & .155 & 3.779 & .000 \\
\hline
\end{tabular}

a. Dependent Variable : Buying Interest

Source: Results of Author's Data Processing.

After testing the coefficient of determination, it is known as follows:

1. Siginifikansi value of the variable $\left(\mathrm{X}_{1}\right)$ Quality of Products $<0.05$ is 0.001 and the regression coefficient is positive, namely 0.095 . This means that there is a significant positive influence individually on product quality variables on buying interest.

2. The significance value of the variable $\left(\mathrm{X}_{2}\right)$ Location $<0.05$ is 0.000 the regression coefficient is positive, namely 0.399 . This means that there is a significant positive influence individually on the price variable on buying interest.

3. The significant value of the variable $\left(\mathrm{X}_{3}\right)$ Location $<0.05$ is 0.000 the regression coefficient is positive, namely 0.203 . This means that there is a significant positive influence individually on the location variable on buying interest.

4. The significance value of the variable $\left(\mathrm{X}_{3}\right)$ Location $<0.05$, ie 0.000 , the regression coefficient is positive, namely 0.115 . This means that there is a significant positive influence individually on the location variable on buying interest.

\section{Conclusions and Practical Implication}

\subsection{Conclusion}

Based on the results of data analysis and descriptive statistics, it can be concluded that: Variable Product Quality $\left(\mathrm{X}_{1}\right)$ positive and significant effect partially to the variable buying interest. So that the first hypothesis $\left(\mathrm{H}_{1}\right)$ is accepted because the results obtained are in accordance with the hypothesis. Price variable $\left(\mathrm{X}_{2}\right)$ has a positive and partially significant effect on the buying interest variable. So that the first hypothesis $\left(\mathrm{H}_{2}\right)$ is accepted because the results obtained are in accordance with the hypothesis. Location variable $\left(\mathrm{X}_{3}\right)$ has a positive and partially significant effect on the buying interest variable. So that the first hypothesis $\left(\mathrm{H}_{3}\right)$ is accepted because the results obtained are in accordance with the hypothesis. Promotion variable $\left(\mathrm{X}_{4}\right)$ has a positive and partially significant effect on the buying interest variable. So the first hypothesis $\left(\mathrm{H}_{4}\right)$ is acceptable because the results obtained are consistent with the hypothesis. 


\subsection{Practical Implication}

Table 5.1. Managerial Implications

\begin{tabular}{|c|c|c|c|}
\hline Variable & Before Research & Research result & After Research Implications for Dira Ashesh \\
\hline $\begin{array}{l}\text { Product } \\
\text { quality }\end{array}$ & $\begin{array}{l}\text { The model or style offered is not so much } \\
\text { variety. Tend to imitate according to those on the } \\
\text { market. }\end{array}$ & $\begin{array}{l}\text { Product quality } \\
\text { affects buying } \\
\text { interest }\end{array}$ & $\begin{array}{l}\text { More up to date to see what kind of style is } \\
\text { developing, for example, for uniform models for } \\
\text { activities on campus, you can see uniform models } \\
\text { for overseas activities with up to date motifs or } \\
\text { words . }\end{array}$ \\
\hline Price & $\begin{array}{l}\text { Prices are not suitable (can change according to } \\
\text { the availability of raw materials and sometimes } \\
\text { too expensive compared to the quality offered) } \\
\text { Many are cheaper than Dira Ashesh }\end{array}$ & $\begin{array}{l}\text { Price } \\
\text { affects buying } \\
\text { interest }\end{array}$ & $\begin{array}{l}\text { 1. Looking for distributors who have a lot } \\
\text { of stock of raw materials or buy directly from } \\
\text { the factory. } \\
\text { 2. Setting the price for each product without } \\
\text { affecting the availability of raw materials } \\
\text { outside. } \\
\text { 3. Reviewing market prices in order to adjust } \\
\text { prices accordingly in order to compete with } \\
\text { other competitors. }\end{array}$ \\
\hline Location & $\begin{array}{l}\text { 1. The unavailability of parking lots for } \\
\text { consumers in large quantities. } \\
\text { 2. The location is not easy to reach by public } \\
\text { transportation because it is not on the } \\
\text { highway. }\end{array}$ & $\begin{array}{l}\text { Location } \\
\text { affects buying } \\
\text { interest }\end{array}$ & $\begin{array}{l}\text { 1. Expanding the parking area for consumers who } \\
\text { come with personal vehicles, both two-wheeled } \\
\text { or four-wheeled. } \\
\text { 2. If you want to move places, pay attention to the } \\
\text { distance to the city center, easy access, and the } \\
\text { availability of adequate parking space } \\
\text { 3. Provide free shipping for Surabaya and Gresik } \\
\text { areas. }\end{array}$ \\
\hline Promotion & $\begin{array}{l}\text { 1. There is no discount for consumers } \\
\text { 2. Haven't applied the pricing plan } \\
\text { 3. No loyalty program } \\
\text { 4. The frequency of promotions is not too } \\
\text { frequent } \\
\text { 5. Promotion only done through word of mouth }\end{array}$ & $\begin{array}{l}\text { Promotion } \\
\text { affects buying } \\
\text { interest. }\end{array}$ & $\begin{array}{l}\text { 1. Increase promotion frequency using social } \\
\text { media such as Instagram, website, tiktok, } \\
\text { facebook, etc } \\
\text { 2. Doing the frequency of promotions more often } \\
\text { and the selection of words in the promotion } \\
\text { is simpler and to the point. } \\
\text { 3. Implement pricing plans and implement loyalty } \\
\text { programs. }\end{array}$ \\
\hline
\end{tabular}

\section{References}

Source: Processed by Researchers.

Amrullah, A. R., \& Agustin, S. (2016). Pengaruh kualitas produk, harga, dan citra merek terhadap keputusan pembelian Honda beat. Jurnal Ilmu Dan Riset Manajemen (JIRM), 5(7), 1-15.

Ghozali, I. (2018). Aplikasi analisis multivariate dengan program IBM SPSS 25. Undip.

Gunawan, G. (2016). Usulan perbaikan kualitas cover dengan menggunakan metode Six Sigma di PT. Era Roda Sukses Bekasi. Universitas Komputer Indonesia.

Hanaysha, J. R. (2018). An examination of the factors affecting consumer's purchase decision in the Malaysian retail market. PSU Research Review, 2(1), 7-23. https://doi.org/10.1108/PRR-08-2017-0034

Hasibuan, M. S. P. (2016). Manajemen: Dasar, pengertian, dan masalah (Revisi). Bumi Aksara.

Kotler, P., \& Keller, K. L. (2009). Manajemen Pemasaran. Jakarta: Erlangga.

Kotler, P., \& Keller, K. L. (2016). Marketing management (15th ed.). New Jersey : Pearson Education South Asia PTe Ltd.

Kurniawan, F., \& Sari, D. (2017). Pengaruh kualitas produk, harga, dan kepercayaan terhadap proses keputusan pembelian konsumen perusahaan konveksi Inglorius Industries di Kota Bandung. EProceedings of Management, 4(1), 735-744.

Kuswatiningsih. (2016). Pemasaran jasa. Yogyakarta: Andi.

Mimi, S. A. (2015). Pengaruh harga, kualitas pelayanan, lokasi dan keragaman produk terhadap keputusan pembelian di Ranch Market. Jurnal Ekonomi, 20(1), 89-102.

Nasution, M. F. R., \& others. (2014). Pengaruh promosi dan harga terhadap minat beli perumahan obama PT. Nailah Adi Kurnia SEI Mencirim Medan. Jurnal Ilmiah Manajemen Dan Bisnis, 14(2), 135-143. https://doi.org/http://dx.doi.org/10.30596\%2Fjimb.v14i2.182 
Oei, I. (2010). Riset sumber daya manusia (Revisi). Gramedia Pustaka Utama.

Priyanto, D. (2014). SPSS 22 pengolahan data terpraktis. Yogyakarta: Andi Offset.

Santoso, S. (2011). SPSS versi 11.5 mengolah data statistik secara profesional. Jakarta: PT Elex Media Komputindo.

Santoso, S. (2012). Panduan lengkap SPSS versi 20. Jakarta: PT Elex Media Komputindo.

Sugiyono, P. D. (2017). Metode Penelitian Bisnis: Pendekatan Kuantitatif, Kualitatif, Kombinasi, dan Rl\&D. Penerbit CV. Alfabeta: Bandung.

Suliyanto. (2018). Metode penelitian bisnis untuk skripsi, tesis, \& disertasi. Yogyakarta: Andi Offset.

Syaparilwadi, P., \& Wardhana, A. (2015). Pengaruh Kualitas Produk Terhadap Kepuasan Pelanggan Pada Perusahaan Konveksi Fazry. EProceedings of Management, 2(3), 3629-3638.

Tjiptono, F. (2015). Strategi pemasaran (Edisi 4). Jakarta: Andi. 